\title{
An Evaluation of Public Expenditure and Economic Growth in Nigeria Using the Sectorial Economic Function Approach
}

\author{
Stanley Chigozie Duruibe, M.Sc \\ Emmanuel E. Chigbu, Ph.D. \\ Emeka Eugene Ejezube, M.Sc \\ Philip Gospel Nwauwa, M.Sc
}

Department of Financial Management Technology,

Federal University of Technology, Owerri, Imo State, Nigeria

Doi:10.19044/esj.2020.v16n7p142～URL:http://dx.doi.org/10.19044/esj.2020.v16n7p142

\begin{abstract}
This study investigates the effect of government public expenditures on Nigeria's economic growth and development using the sectorial economic function approach. The real Gross Domestic Product (GDP), which is the outcome variable in this study, was employed as the proxy for economic growth while government's expenditures on administrative services, economic services, social and community services, and transfers were used as the predictor variables in this study. Surprisingly, the results from the cointegration test and Vector Error Correction Model estimate reveal that all the predictor variables, apart from expenditure on administration, have a positive relationship with economic growth. While expenditures on economic services and social and community services have positive and significant relationship with economic growth, government transfers has a positive but insignificant relationship with economic growth. Emphatically, expenditure on administrative services has a significant negative relationship with economic growth. The result from Wald coefficient diagnostic test reveals that there is short run causality running from the public expenditure aggregates to economic growth. Thus, this study recommends, among others, that efforts should be made to reduce the deadweight aggregate public expenditure on administrative services since it has a significant negative impact on economic growth trend in Nigeria.
\end{abstract}

Keywords: Public Expenditure, Economic Growth, Vector Error Correction Model, Nigeria 


\section{Introduction}

This study would not have been necessary if the steady growth in Nigeria's public expenditure over the years has been accompanied by a visible and proportionate growth in the various sectors that make up the Nigerian economy. Between the year 1999 (i.e. when the country returned to democratic rule) and 2016, the federal recurrent expenditure increased from 449.66 billion naira to $4,178.59$ billion naira, an increase of $829.28 \%$, while federal capital expenditure increased from 498.03 billion to 634.79 billion naira, an increase of $27.4 \%$. In the same period, GDP growth rate averaged $6.64 \%$ (CBN Statistical Bulletin, 2017). Economic theory assert that public expenditure on all sectors of the economy is expected to lead to economic growth and development in the sense that capital and recurrent expenditure will reinforce the productive base of the economy which will naturally support economic growth and development.

Government expenditures in Nigeria are broadly classified into expenditures in government functions such as administration, social and community services, economic services and transfers. Expenditures on general administration, defense, internal security and national assembly come under administration. Expenditure on social and community services captures expenditures on education, health and other social and community services. Expenditure on economic services includes those on agriculture, transport, construction and communication and other economic services. Government transfers include public debt servicing, pensions and gratuities, contingencies/subventions, etc. (CBN Statistical Bulletin, 2017). All these classes of government expenditures, apart from government transfers, have capital and recurrent components. Capital expenditure is primarily expenditure on the creation of fixed assets that will generate future benefits, and on the acquisition of land, buildings and intangible assets. Recurrent expenditure, on the other hand, refers to expenditure on operations, wages and salaries, purchases of goods and services, and current grants and subsidies.

Government expenditure constitutes a major element in the National income estimates using the expenditure method. Thus, government expenditure is a contributing factor to the size and growth of the economy. Its contributions to economic growth could come with positive or negative consequence. For instance, in developing countries where there are market failures, it can encourage aggregate output growth or have adverse effect such as inflation and boom-bust cycles (Wang and Wen, 2013). In Nigeria, government expenditures have had conflicting results on the economy. In the wake of the Structural Adjustment Program (SAP) in 1986, the economy contracted by $-8.75 \%$ and $-10.75 \%$ in 1986 and 1987 respectively when government expenditure expanded by $18.9 \%$ within the same period, 1986 (CBN Statistical Bulletin, 2017).More so, a critical look at the growth trend of 
annual government expenditures over the years will reveal that government spending has grown more proportionately than the crowding effect of the economy. Furthermore, Nigeria has been referred as the poverty capital of the world with over 80 million people living in abject poverty. Infrastructures such as road, power, housing, water supply are comatose. Many firms are either moribund or the few ones which have been able to weather the storm are fleeing to neighboring countries in droves. Unemployment is on the rise and several of Nigeria's macroeconomic indicators show that the country is not doing well at all (Ebiringa and Duruibe, 2015). In the light of the foregoing, the aim of this study is to investigate the correlation between government expenditures and economic growth in Nigeria. This is with the view to updating the extant literature in the public expenditure-growth nexus debate.

The remainder of this paper is structured as follows: literature review comes after this section; data analysis and empirical results are presented and discussed in the third section; section four summarizes and concludes the study and thereafter proffers some policy recommendations; while section five provides the references.

\section{Literature Review}

The existing literatures in the public finance-growth debate domain have emerged with divergent views. For instance, while Korman and Brahmasrene (2007), Gregorious and Ghosh (2007), Aregbeyen (2007), Sinha (1998), Loizides and Vamvoukas (2004), Alexiou (2009), Cooray (2009) and Muritala and Taiwo (2011), amongst others, documented a positive and significant impact of government expenditure on economic growth; others such as Akpan (2005), Laudau (1983), Nurudeen and Usman (2010) amongst others documented a negative or non-significant relationship. Kormain and Brahmasrene (2007) analyzed the economy of Thailand with the Granger causality tests. They find that government expenditures and economic growth are not co-integrated. However, they indicate a one-dimensional relationship as causality runs from government expenditure to growth. Furthermore, they find a significant positive impact of government spending on economic growth. Gregorious and Ghosh (2007) find that countries with large government expenditure are inclined to experience higher growth. They used the heterogeneous panel data to study the impact of government expenditure on economic growth. Aregbeyen (2007), established a positive and significant relationship between government capital and public investment and economic growth. However, he finds that recurrent consumption expenditure is negatively related to economic growth. Sinha (1998) studied the relationship between government expenditure and GDP in China, and finds that a strong positive correlation exists between government expenditure and GDP. The test of Granger causality indicates that there is weak evidence of 
unidirectional causality running from government expenditure to GDP. Loizides and Vamvoukas (2004) examined the causal relationship between the relative size of government and economic growth rate using data on UK, Ireland and Greece. They discover that government size, measured as the share of total expenditure in GNP, granger causes economic growth rate in the short run in all the three countries, while in the long run government size granger causes economic growth rate in Ireland and UK alone, and that economic growth granger causes increase in the relative size of government in Greece and Ireland when inflation rate is included. Similarly, a study conducted by Alexiou (2009) on seven transition economies in South Eastern Europe using the panel data method shows indication of a significant positive effect of government spending on capital formation on economic growth. Also, Cooray (2009) examined the function of the government in economic growth by expanding the neoclassical production function to integrate the two dimensions of government which are - the size dimension (measured by government expenditure) and quality dimension (measured by governance) for a cross-section of 71 economies. The empirical results indicate that both dimensions of government are significant to explain economic growth trend. Muritala and Taiwo (2011), examined the impact of recurrent and capital expenditure on economic growth and find that both components of government expenditure have positive and significant impact on economic growth.

Akpan (2005), on the other hand, employed the disaggregated method to ascertain the components of government expenditure that promote growth. He concludes that there is no significant correlation between most components of government expenditure and economic growth in Nigeria. Laudau (1983) also studied the impact of government consumption expenditure on economic growth for a selected 96 countries and finds that there is a negative effect of government expenditure on economic growth. Furthermore, in a study conducted by Nurudeen and Usman (2010) to examine the impact of government expenditure (disaggregated into various components) on economic growth in Nigeria between 1970-2008, they find that government total capital expenditure, total recurrent expenditure and expenditure on education have negative effect on economic growth. However, expenditure on transport, communication and health were seen to have positive impact on growth.

Similarly, Loto (2011), employed the Error Correction Mechanism to examine the impact of government expenditures on various sector of the Nigerian economy such as: education, health, national security, transportation and communication, and agriculture- between 1980 and 2000 and finds that government expenditure on education and agriculture impact negatively on economic growth, although the negative impact of expenditure on education 
on economic growth is not significant. The impact of expenditure on the health sector on economic growth is seen to be positive and significant, while the impact of expenditure on national security, transportation and communication are seen to be positive but statistically insignificant. In his study of the Jordan economy, Dandan (2011) employed time series data spanning from 1990 to 2006 in his regression model and finds that government expenditure at the aggregate level has positive impact on the growth of GDP. He also finds that interest payment (a control variable in the model) has no effect on economic growth. Onakoya and Somole (2013) used the three-stage least square simultaneous equations estimation technique to investigate the effect of public capital expenditure on economic growth in Nigeria and find that public capital expenditure significantly contributes to economic growth in Nigeria. The results of the study also reveal that public capital expenditure directly and positively affect the output of oil and manufacturing, but adversely affected the output of manufacturing and agriculture. The effect on the services sector is however seen to be immaterial. More evidence from the study reveals that public capital expenditure implicitly promotes economic growth by advancing private sector investment owing to government aid through the provision of public goods and infrastructure.

Going further, it will be imperative to also revisit some of the economic theories that determine the growth of public expenditure, among which are Wagner's law of increasing state activity, Wiseman are and Peacock displacement effect, Keynesian and the Leviathan hypotheses. In specific terms, Wagner's law of increasing State activity or the law of expanding State role states, in a nut shell, that as the economy expands, the rate of government expenditure rises accordingly. In this case, the growth of government expenditure is as a result of economic growth and development. This theory is entrenched on the notion that as industrialization progresses, the real income per capita of a country increases, thereby increasing the share of public expenditure in the Gross National Product (Serena and Andrea, 2011; Babatunde, 2011; Magazzino et al, 2015. ). This means that increase in public expenditure arises in order to maintain the pace of the industrial and growth activities.

Another notable theory of public expenditure growth is contained in the groundbreaking work of Peacock and Wiseman (1961). Peacock and Wiseman theory concentrates on the pattern of public expenditure and they aver that public expenditure occurs in steps or jerks and does not follow a smooth process. According to their treatise, as a result of some social upheavals in an economy, government increases tax to raise more revenue to facilitate an increase in public expenditure that will off-set the social disturbance. This gives rise to a displacement effect where low taxes and expenditures are replaced by higher taxes and expenditures. However, after 
the disturbance, the new level of tax tolerance makes the people eager to embrace higher level of public expenditure since they are capable of bearing higher tax burden than before. Thus, the new level of public expenditure and revenue stabilize but are later destabilizes by yet another new social disturbance which triggers another displacement effect. In effect, the need to increase expenditure arises since the existing expenditure cannot solve the problem. Thus, the fiscal activities of the government rise gradually to continuous new higher levels over the preceding years to meet successive social upheavals. Even if there is no new disturbance, government expenditure does not usually go down to its previous level. Sanjeev, De Mello and Sharan (2001) confirmed this displacement theory in their study where the studied some 120 countries using panel regression techniques and come to the conclusion that total government expenditure and arms purchasing relative to GDP rises in the course of political disturbance.

The Keynesian theory supports increase government expenditure and lower taxes to stimulate demand and pull an economy out of recession or depression. However, it is recommended that policy makers should be fast to reduce public expenditure as soon as the economy recovers from a recession to avert inflation (Mitchell, 2005).

Another theory that explains government expenditure is the Leviathan theory. Geoffrey Brennan and James Buchanan (1980) first developed this theory of government in their book, The Power to Tax. This theory holds that government tries to get control of as much of the economy as possible. However, the aggregate government's involvement in the economy will be lessened as the taxes and expenditures are reduced, other things being equal. Rodden (2003) avers that the Leviathan theory stems from the fact that the central government is seen as a 'revenue maximizing leviathan' that seeks to maximize her revenue by fiscal devolution of the central government monopoly on taxation. This theory holds that the more devolved the central government, the lesser the government spends in the economy since the devolved unit will be in charge of revenue generation and expenditure payout. Accordingly, the burden on the central government lessens as part of this burden is transmitted to the subordinate units.

\section{Methodology, Data Analysis, Empirical Results and Discusion Methodology}

Secondary data was exclusively used in this study and the data was analyzed using Eviews10. These data were sourced from the World Bank databank and the Central Bank of Nigeria statistical bulletin 2017, and it spans from 1986 to 2016. Various econometric techniques where employed descriptive statistics, unit root tests, co-integration test, Vector Equilibrium 
Correction Model, residual diagnostic tests, and Wald coefficient diagnostic test. Details of these tests are contained in the next section.

Data Analysis and Empirical Results

Table 1. Descriptive Statistics

\begin{tabular}{|l|l|l|l|l|l|}
\hline & GDP & ADMIN & ECONS & SOC & TRANS \\
\hline Mean & 34530.04 & 515.6277 & 321.8026 & 290.8061 & 532.0048 \\
\hline Median & 25267.54 & 230.0500 & 226.5000 & 132.9600 & 250.3900 \\
\hline Maximum & 69023.93 & 1494.200 & 974.9500 & 998.7800 & 2190.950 \\
\hline Minimum & 15237.99 & 1.710000 & 1.380000 & 0.920000 & 12.01000 \\
\hline Std. Dev. & 18086.69 & 550.7702 & 308.1603 & 348.9308 & 573.7158 \\
\hline Skewness & 0.708861 & 0.633810 & 0.654348 & 0.931897 & 1.201651 \\
\hline Kurtosis & 2.026670 & 1.778265 & 2.189582 & 2.257585 & 3.678156 \\
\hline \multicolumn{7}{|l|}{} \\
\hline Jarque-Bera & 3.819854 & 4.003517 & 3.060557 & 5.198842 & 8.054519 \\
\hline Probability & 0.148091 & 0.135098 & 0.216475 & 0.074317 & 0.017823 \\
\hline \multicolumn{7}{|l|}{} \\
\hline Sum & 1070431. & 15984.46 & 9975.880 & 9014.990 & 16492.15 \\
\hline Sum Sq. Dev. & $9.81 \mathrm{E}+09$ & 9100436. & 2848883. & 3652582. & 9874496. \\
\hline Observations & 31 & 31 & 31 & 31 \\
\hline
\end{tabular}

Source: Eviews10

From the descriptive statistics of 31 series in each of the variables in table 1, the mean and median show the average values and middle values of each of the variables respectively. The maximum and minimum show the highest and lowest variables in each of the series. The standard deviation shows how far the observations are from the sample average. The skewness measures the degree of asymmetry of the series. All the variables, apart from TRANS (Government Transfers), mirrors normal skewness as each of their values is close to zero. TRANS skewness of 1.2 has a long right tail and is positively skewed. The kurtosis measures the peakness or flatness of the curve. - All the variables, apart from TRANS (Government Transfers), mirrors negative kurtosis (or platykurtic) as each of their values is less than 3. TRANS is leptokurtic (positive kurtosis) because 3.67 is greater than 3. More so, each of the variables, apart from TRANS, is normally distributed. 
Table 2. Results from the Augmented Dickey Fuller Unit Roots Test

\begin{tabular}{|l|l|l|l|l|l|}
\hline \multicolumn{2}{|c|}{ Augmented Dickey Fuller Unit Roots Test Results Probability Values } \\
\hline & GDP & ADMIN & ECONS & SOC & TRANS \\
\hline Level & 0.7556 & 0.9336 & 0.6233 & 0.9876 & 1.0000 \\
\hline $1^{\text {st }}$ difference & 0.3647 & $0.0000^{*}$ & $0.0001^{*}$ & $0.0040^{*}$ & $0.0029^{*}$ \\
\hline $\begin{array}{l}2^{\text {nd }} \\
\text { difference }\end{array}$ & $0.0014^{*}$ & $0.0000^{*}$ & $0.0000^{*}$ & $0.0000^{*}$ & $0.0003^{*}$ \\
\cline { 1 - 4 } Kwiatkowski, Phillips, Schmidt, And Shin (KPSS) Unit Root Confirmation Test For \\
GDP
\end{tabular}

Source: Eviews10 N.B: *denotes stationary series

From table 2 above, all the variables were not stationary at levels, hence they were converted to $1^{\text {st }}$ and $2^{\text {nd }}$ difference. Apart from GDP which is stationary at $2^{\text {nd }}$ difference, all the other variables were stationary at $1^{\text {st }}$ difference. However, when the Kwiatkowski, Phillips, Schmidt, and Shin (KPSS) unit root test was applied to GDP to confirm its level of stationary, KPSS found it to be stationary at the $1^{\text {st }}$ difference. According to Katircioglu, Feridun and Kilinc (2014), Farhani and Ozturk (2015), and Behera and Dash (2017), the ADF unit root tests have a lower power of rejecting the null hypothesis. Thus, the Kwiatkowski, Phillips, Schmidt, and Shin (KPSS) unit root test surpasses the ADF unit root test in eliminating a possible low power against stationary unit root that occurs in them . KPSS has the additional advantage of yielding consistent results for variables with lower number of observation such as what is obtainable in this study. Thus, the variables are taken to be stationary at first difference.

Table 3. Lag Order Selection Criteria for Co-Integration and VECM.

Endogenous variables: GDP ADMIN ECONS SOC TRANS

\begin{tabular}{|l|l|l|l|l|l|l|}
\hline Lag & LogL & LR & FPE & AIC & SC & HQ \\
\hline 0 & -1024.708 & NA & $4.77 \mathrm{e}+24$ & 71.01433 & 71.25007 & 71.08816 \\
\hline 1 & -881.0509 & 227.8696 & $1.37 \mathrm{e}+21$ & 62.83110 & 64.24554 & 63.27408 \\
\hline 2 & -828.2017 & $65.60598^{*}$ & $2.38 \mathrm{e}+20^{*}$ & $60.91046^{*}$ & $63.50361^{*}$ & $61.72260^{*}$ \\
\hline * indicates lag order selected by the criterion \\
LR: sequential modified LR test statistic (each test at 5\% level) \\
FPE: Final prediction error \\
AIC: Akaike information criterion \\
SC: Schwarz information criterion \\
HQ: Hannan-Quinn information criterion
\end{tabular}

Source: Eviews10

The lag order selection criteria in table 3 opined that lag 2 should be used as majority of the criterion selected 2 . This is shown by the dominant 
appearance of the asterisks in the lag 2 row. Thus, in running the co-integration test and Vector Error Correction Model, Lag 2 will be used.

Table 4. Johansen Co-integration Test

Included observations: 28 after adjustment. Trend assumption: Linear deterministic trend Series: GDP ADMIN ECONS SOC TRANS Lags interval (in first differences): 1 to 2

\begin{tabular}{|c|c|c|c|c|}
\hline \multicolumn{5}{|c|}{ Unrestricted Co-integration Rank Test (Trace) } \\
\hline $\begin{array}{l}\text { Hypothesized No. } \\
\text { of C.E }\end{array}$ & Eigenvalue & Trace Statistic & $\begin{array}{l}\text { Critical } \\
\text { Value(0.05) }\end{array}$ & Prob. \\
\hline None $*$ & 0.970879 & 225.7585 & 69.81889 & 0.0000 \\
\hline At most $1 *$ & 0.941477 & 126.7426 & 47.85613 & 0.0000 \\
\hline At most $2 *$ & 0.614607 & 47.26909 & 29.79707 & 0.0002 \\
\hline At most $3 *$ & 0.492122 & 20.57129 & 15.49471 & 0.0079 \\
\hline At most 4 & 0.055570 & 1.600875 & 3.841466 & 0.2058 \\
\hline \multicolumn{5}{|c|}{ Unrestricted Co-integration Rank Test (Maximum Eigenvalue) } \\
\hline $\begin{array}{l}\text { Hypothesized No. } \\
\text { of C.E }\end{array}$ & Eigenvalue & $\begin{array}{l}\text { Max-Eigen } \\
\text { Statistic }\end{array}$ & $\begin{array}{l}\text { Critical } \\
\text { Value(0.05) }\end{array}$ & Prob. \\
\hline None $*$ & 0.970879 & 99.01589 & 33.87687 & 0.0000 \\
\hline At most $1 *$ & 0.941477 & 79.47355 & 27.58434 & 0.0000 \\
\hline At most $2 *$ & 0.614607 & 26.69780 & 21.13162 & 0.0074 \\
\hline At most $3 *$ & 0.492122 & 18.97042 & 14.26460 & 0.0084 \\
\hline At most 4 & 0.055570 & 1.600875 & 3.841466 & 0.2058 \\
\hline
\end{tabular}

Trace test indicates 1 co-integrating equation at the 0.05 level.

Max-eigenvalue test indicates 1 co-integrating equation at the 0.05 level.

* denotes rejection of the hypothesis at the 0.05 level.

**MacKinnon-Haug-Michelis (1999) p-values

\section{Source: Eviews10}

From table 4 above, the trace and max-eigenvalue test show that there are four Error Correction Terms or co-integrating equation. The existence of co-integration among the variables indicates that there is a long run equilibrium relationship among the variables in the model.

The econometric model below was regressed using the VECM technique and the output in table 5 below was obtained:

$\Delta \mathrm{Y}_{\mathrm{t}}=\beta_{0}+\sum_{\mathrm{x}}^{\mathrm{p}}=\mathrm{i} \beta_{1} \mathrm{Y}_{\mathrm{t}-\mathrm{i}}+\sum_{\mathrm{x}}^{\mathrm{p}}=\mathrm{i} \beta_{2} \operatorname{ADMIN}_{\mathrm{t}-\mathrm{n}}+\sum_{\mathrm{x}}^{\mathrm{p}}=\mathrm{i} \beta_{3} \mathrm{ECONS}_{\mathrm{t}-\mathrm{n}}+\sum_{\mathrm{x}} \mathrm{x}^{\mathrm{p}}=1 \beta_{4} \mathrm{SOC}_{\mathrm{t}-\mathrm{n}}$ $+\sum_{\mathrm{x}}^{\mathrm{p}}=1 \beta_{5}$ TRANS $_{\mathrm{t}-\mathrm{n}}+d_{1} \operatorname{VAR}(-1)+\mathrm{E}_{\mathrm{t}}$

\section{WHERE:}

The a priori expectation is: $\beta_{1}>0, \beta_{2}>0, \beta_{3}>0, \beta_{4}, \beta_{5}>0$

\section{And:}

$\mathbf{Y}=$ Real GDP, the proxy for economic growth;

ADMIN=Expenditures on general administration, defense, internal security and national assembly; 
ECONS= Expenditure on economic services include expenditures on agriculture, transport, construction and communication and other economic services. Expenditure in these areas reduces production cost, increases private sector investment and profitability of firms which ultimately boosts the overall economic activities in the country;

SOC $=$ Expenditure on social and community services includes expenditures on education, health and other social and community services. Expenditure in these areas boosts the productivity of labor and increase the growth of national output;

TRANS $=$ Government transfers include public debt servicing, pensions and gratuities, contingencies/subventions, etc.

d $_{\mathbf{1}} \operatorname{VAR}(-\mathbf{- 1})=$ Error Correction Term .

$\mathbf{E}_{\mathrm{t}}=$ Disturbance term.

$\mathbf{B}_{\mathbf{0}}=$ Intercept.

$\boldsymbol{\beta}_{1}, \boldsymbol{\beta}_{2}, \boldsymbol{\beta}_{3}, \boldsymbol{\beta}_{\mathbf{4}}, \boldsymbol{\beta}_{\mathbf{5}}=$ Coefficients to be estimated.

The data for all the variables was sourced from the CBN Statistical bulletin 2017 and it spans from 1986-2016. We had few missing data which warranted an interpolation with Eviews10 to obtain missing the data.

Tests of heteroskedasticity, serial correlation and normality were further conducted to check model adequacy. Outputs of the tests are shown in table 6 .

Table 5. Vector Equilibrium Correction Model

Dependent Variable: D(GDP); Sample (adjusted): 1988 2016; Included observations: 29 after adjustments; Method: Least Squares Gauss-Newton / Marquardt steps

\begin{tabular}{|c|c|c|c|c|}
\hline & Coefficients & Std. Error & t-Statistic & Prob. \\
\hline ECT(-1) & 0.013984 & 0.007151 & 1.955459 & 0.0633 \\
\hline D $\{$ GDP $(-1)\}$ & 0.738232 & 0.134626 & 5.483591 & 0.0000 \\
\hline D\{ADMIN(-1)\} & -10.77193 & 2.789768 & -3.861227 & 0.0008 \\
\hline D $\{\operatorname{ECONS}(-1)\}$ & 4.132928 & 1.471884 & 2.807917 & 0.0102 \\
\hline $\mathrm{D}\{\operatorname{SOC}(-1)\}$ & 15.60087 & 4.763914 & 3.274800 & 0.0035 \\
\hline D $\{$ TRANS(-1)\} & 1.203180 & 1.592065 & 0.755735 & 0.4578 \\
\hline $\mathbf{C}$ & 350.5963 & 268.0294 & 1.308052 & 0.2044 \\
\hline \multicolumn{5}{|c|}{ SUMMARY STATISTICS. } \\
\hline R-squared & 0.741712 & & Mean dep Var & 1816.114 \\
\hline Adjusted R-squared & 0.671269 & & S.D. dep Var & 1482.807 \\
\hline S.E. of regression & 850.1680 & & Akaike info criterion & 16.53525 \\
\hline Sum squared resid & 15901285 & & Schwarz criterion & 16.86529 \\
\hline Log likelihood & -232.7611 & & Hannan-Quinn criter. & 16.63861 \\
\hline F-statistic & 10.52935 & & Durbin-Watson stat & 2.109576 \\
\hline Prob(F-statistic) & 0.000016 & & & \\
\hline
\end{tabular}

Source: Eviews10 
Table 6. Residual Diagnostic Tests

\begin{tabular}{|l|l|l|l|}
\hline TEST & $\begin{array}{l}\text { OBSERVED } \\
\mathbf{R}^{2} / \text { JARQUE-BERA. }\end{array}$ & PROBABILITY & INTERPRETATION. \\
\hline $\begin{array}{l}\text { Breusch-Godfrey Serial } \\
\text { Correlation LM Test: }\end{array}$ & $\mathbf{1 . 0 5 3 2 8 3}$ & $\mathbf{0 . 5 9 0 6}$ & Desirable \\
\hline $\begin{array}{l}\text { Heteroskedasticity Test: } \\
\text { Breusch-Pagan-Godfrey }\end{array}$ & 9.485513 & $\mathbf{0 . 4 8 6 7}$ & Desirable \\
\hline $\begin{array}{l}\text { Jarque-Bera Test of } \\
\text { Normality: }\end{array}$ & $\mathbf{0 . 7 1 6 3 5 6}$ & $\mathbf{0 . 6 9 8 9 4 9}$ & Desirable. \\
\hline
\end{tabular}

Source: Eviews10

Table 7. Wald Coefficients Diagnostic Test

\begin{tabular}{|l|l|l|l|}
\hline \multicolumn{4}{|l|}{$\mathbf{H}_{0}=$ D $\{$ ADMIN(-1) $\}=$ D $\{$ ECONS(-1) $\}=$ D $\{$ SOC(-1) $\}=$ D $\{$ TRANS(-1) $\}=0$} \\
\hline TEST STATISTIC & VALUE & df & PROBABILITY \\
\hline F-statistic & 5.040628 & $(4,22)$ & 0.0049 \\
\hline Chi-square & $\mathbf{2 0 . 1 6 2 5 1}$ & $\mathbf{4}$ & $\mathbf{0 . 0 0 0 5}$ \\
\hline
\end{tabular}

INTERPRETATION: There is a short run causality running from the independent variable to the dependent variable.

Source: Eviews10

\section{Discussion of Results}

From the table 5 above, the correlation coefficient $\left(\mathrm{r}^{2}\right)$ of approximately $74 \%$ denotes a good model fit. This means that up to $74 \%$ of the variation in the outcome variable is explained by the explanatory variables. This implies that only 26 percent of the variation is accounted for by variables not considered in the model. The significant F-statistic (0.000016) indicates that all the independent variables can jointly influence the dependent variable. Durbin Watson Statistics is in the threshold of 2 which signals the nonexistence of autocorrelation. All the results of the residual diagnostic tests conducted and displayed in table 6 are desirable results. Results from Wald coefficient diagnostic test in table 7 above shows that there is short run causality running from independent to dependent variable.

All the explanatory variables, apart from expenditure on administration (ADMIN) as shown in table 5 above, have a positive relationship with GDP. Expenditures on economic and social services have positive and significant relationship with GDP, while government transfer has a positive but insignificant relationship with GDP. This implies that channeling more expenditure to these sectors: agriculture, transport, construction communication, education, health and other economic, social, and community services is plausible as it propels the engine of economic growth and development in Nigeria. More so, expenditures on public debt servicing, pensions and gratuities, contingencies/subventions have an insignificant impact on economic growth. It is noteworthy to reiterate here that expenditures on general administration, defense, internal security and national assembly have a significant negative relationship with GDP. 
There is no doubt in this finding as the expenditure on administration has been monumentally high over the years. Reacting to this ugly trend, Sanusi (2010) aver that the share of National Assembly budget in the federal government overhead budget is $25 \%$ in 2010 . Moreover, recall that we earlier noted in the introductory part of this study that between 1999 and 2016, federal recurrent expenditure increased by $829.28 \%$, while federal capital expenditure grew by only $27.4 \%$. This incident is not in tune with economic realities, especially for a developing nation like Nigeria. Expenditures on internal security, defense and general administration have not been left out. Ordinarily, government expenditure on defense and internal security secures the nation from external and internal aggression which will ultimately provide a safe haven for investors to invest their capital thereby attracting the inflow of Foreign Direct Investment. It is, however, unfortunate that despite the billions of dollars spent annually over the years to tame various forms of security challenges in the country posed by the Boko-Haram terrorists, Fulani herdsmen, kidnappers, youth restiveness in different parts of the nation, among others, have continued unabated. This situation tend to have a significant negative effect on the nation's economic growth and development as it discourages the inflow of foreign investments and the enabling environment required to do business. Moreover government spend so much on general administration, which is recurrent in nature, thereby shutting down funding to the key growth enhancing sectors such as education, health and economic services. Higher spending on general administration is a deadweight spending which derails the impact of government expenditure on economic growth.

\section{Summary, Conclusinon and Recommendation}

So far, this paper evaluates, in an empirical manner, the impact of sectorial aggregate expenditure on Nigeria's economic growth and development. These sectors were aggregated into administrative services which comprises expenditures on general administration, defense, internal security and national assembly; economic services which include expenditures on agriculture, transport, construction and communication and other economic services; social and community services comprises of expenditures on education, health and other social and community services; and government transfer payment which includes debt servicing, pensions and gratuities, contingencies/subventions, subsidy etc. The aim thereof is to ascertain which combination of sectors play significant role in the economic prosperity of the country. The data for this study was sourced from the Central Bank of Nigeria Statistical Bulletin of 2017 and analyzed using various statistical analytical tools such as descriptive statistics, co-integration, vector equilibrium correction mechanism and the Wald test. This study find that expenditures on 
economic, social and community services have positive and significant relationship with GDP; government transfer have a positive but insignificant relationship with GDP; and government expenditure on administrative services have a negative and significant relationship with GDP.

These findings, therefore, validate the following assertions:

- Expenditures on economic services such as agriculture, transport, construction and communication and other economic services will reduces production cost, increases private sector investment and profitability of firms which ultimately boosts the overall economic growth in the country;

- Expenditures on social and community services which incorporate expenditures on education, health and other social and community services will boosts the productivity of labor and increase the growth of national output;

- The preponderance of recurrent expenditure over capital expenditure has been inimical to the country's economy

Thus, efforts should, therefore, be made to reduce the deadweight public expenditure on administrative services as this study shows that this expenditure aggregate has a significant negative impact on economic growth trend in Nigeria.

\section{References:}

1. Akpan, N. (2005). Government Expenditure and Economic Growth in Nigeria: A Disaggregated Approach. CBN Economic and Financial Review, 43(1), 5-12.

2. Alexiou, C. (2009). Government Spending and Economic Growth: Economic Evidence from the South Eastern Europe. Journal of Economic and Social Research, 11(1), 1-16.

3. Aregbeyen, O. (2007). Public Expenditure and Economic Growth. African Journal of Economic Policy, Ibadan (Nigeria): University of Ibadan Press 1 (1). 4-9.

4. Babatunde, M.A. (2011). A Bound Testing Analysis of Wagner's Law in Nigeria: 1970-2006. Applied Economics, 43(21), 2843-2850.

5. Behera, S. R., \& Dash, D. P. (2017). The Effect of Urbanization, Energy Consumption, and Foreign Direct Investment on the Carbon Dioxide Emission in the SSEA (South and Southeast Asian) Region. Renewable and Sustainable Energy Reviews, 70, 96-106.

6. Central Bank of Nigeria Statistical Bulletin 2017.

7. Cooray, A. V.(2009). Government Expenditure, Governance and Economic Growth. Comparative Economic Studies, 51(3), 401-418. 
8. Dandan, M. M. (2011). Government Expenditure and Economic Growth in Jordan. IPEDR, 4, 467-471.

9. Ebiringa, O.T. \& Duruibe, S.C. (2015). Financial System Development and Economic Growth: Evidence from Nigeria. American Journal of Economics, Finance, and Management, 1(5), 329-335.

10. Eze, O. (2017). Implementing the 2017 federal capital budget. Retrieved from https://punchng.com/implementing-the-2017-federalcapital-budget/

11. Farhani, S., \& Ozturk, I. (2015). Causal Relationship between CO2 Emissions , Real GDP , Energy Consumption, Financial Development , Trade, Consumption, and Trade Openness . Environmental Science and Pollution Research, (October), 4767-71. doi.org/10.1007/s11356015.

12. Geoffrey, B. \& James, B. (1980). The Power to Tax: Analytic Foundations of a Fiscal Constitution. Cambridge University Press, London.

13. Gregorious, A. \& Ghosh, S. (2007). The Impact of Government Expenditure on Growth: Empirical Evidence from Heterogeneous Panel. Retrieved from http://www.brunel.ac.uk/9379/efwps/0701.pdf

14. Katircioglu , S. T., Feridun , M., \& Kilinc , C. (2014). Estimating Tourism-Induced Energy Consumption and CO2 Emissions: The Case of Cyprus. Renewable and Sustainable Energy Reviews, 29, 634-640.

15. Koman, J \& Bratimasrene, T. (2007). The Relationship between Government Expenditure and Economic Growth in Thailand. Journal of Economic Education, 14, 234-246.

16. Laudau D. (1983). Government Expenditure and Economic Growth: A Cross Country Study. Southern Economic Journal, 49, 783-792.

17. Landau, D. L. (1986). Government and Economic Growth in the Less Developed Countries: An Empirical Study from 1960-1988. Economic Development and Cultural Change, 35, 35-75.

18. Loizides, J. \& Vamvoukas, G. (2004). Government Expenditure and Economic Growth: Evidence from Trivariate Causality Testing. Journal of Applied Economics, 8(1), 125-152.

19. Loto, M. A. (2011). Impact of Government Sectorial Expenditure on Economic Growth. Journal of Economics and International Finance, 3(11), 646-652.

20. Mackinnon, J.G; A. Haug \& L. Michelis (1999). Numerical Distribution Functions of Likelihood Ratio Tests for Co-integration. Journal of Applied Econometrics, 14, 563-577.

21. Magazzino, C., Giolli, L., Mele, M., (2015). Wagner's Law and Peacock and Wiseman's Displacement Effect in European Union 
Countries: A Panel Data Study. International Journal of Economics and Financial Issues, 5(3), 812-819.

22. Muritala T. \& Taiwo, A. (2011). Government Expenditure and Economic Development: Empirical Evidence from Nigeria. European Journal of Business and Management, 3(9), 18-28.

23. Mitchell, D. J. (2005). The Impact of Government Spending on Economic Growth. Executive Summary Backgrounder, 18-31.

24. Nurudeen, A. \& Usman, A. (2010). Government Expenditure and Economic Growth in Nigeria: A Disaggregated Analysis. Business and Economics Journal, 2010(4), 1-11.

25. Onakoya, A. B. and Somole, R. O. C. (2013). The Impact of Public Capital Expenditure on Economic Growth in Nigeria. Global Journal of Economics and Finance, 2(1), 1-11.

26. Peacock, A.T., \& Wiseman, J. (1961). Determinants of Government Expenditure. NBER Chapters, in: The Growth of Public Expenditure in the United Kingdom. Retrieved from http://www.nber.org/chapters/c2302.

27. Rodden, J. (2003). Reviving Leviathan: Fiscal Federalism and the Growth of Government. International Organization, 57, 695-729.

28. Serena, L. \& Andrea, Z. (2011). Increasing Public Expenditures: Wagner's Law in OECD Countries. German Economic Review, 12(2), 149- 164.

29. Sanjeev, G., De Mello, L., \& Sharan, R. (2001). Corruption and Military Spending. European Journal of Political Economy, 17(4), 749-777.

30. Sinha, D. (1998). Economic Growth and Government Expenditure in China. Retrieved from: http://mpra.ub.unimuenchen.de/18347/1/MPRA_paper_18347.pdf.

31. Sanusi, L. (2010). National Assembly Spends 25\% of Budget. Retrieved from http:the Nigerianvoice.com.

32. Wang, X, \& Wen, Y. (2013). Is Government Spending a Free Lunch? Evidence from China. Retrieved from http:// research. stlouisfed. org/ wp / 2013/2013-013.pdf 